\title{
Deregulation of miR-34a, miR-221 and miR-222 after HT29 cells treatment with Silibinin encapsulated in polymersomes as an anti-cancer stem cell agent
}

\section{Samaneh Hosseinzadeh ( $\boldsymbol{\nabla}$ shosseinzadeh@endocrine.ac.ir)}

Research Institute for Endocrine Sciences, Shahid Beheshti University of Medical Sciences https://orcid.org/0000-0002-3313-4094

\section{Safura Pakizehkar}

Research Institute for Endocrine Sciences

Najmeh Ranji

Islamic Azad University Rasht Branch https://orcid.org/0000-0001-5233-2427

\section{Alireza Naderi Sohi}

Stemcell technology reseach center

\section{Farhood Najafi}

institute for color science and technology

\section{Research Article}

Keywords: Nano-drug Delivery, MicroRNAs, Silibinin, Colorectal Cancer, Stem Cell

Posted Date: March 9th, 2021

DOl: https://doi.org/10.21203/rs.3.rs-164209/v1

License: (c) (1) This work is licensed under a Creative Commons Attribution 4.0 International License. Read Full License 


\section{Abstract}

Colorectal Cancer (CRC) has the most common malignant gastrointestinal cancer which representing about $13 \%$ of all malignant tumor. CRC Cancer Stem Cell is the major reasons for recurrence of disease cause of solid tumor metastasis, relapse of cancer after treatment and drug resistance. Silibinin, an herbal extract from milk thistle plant, has been identified as a potential cancer medicine that can target the signaling pathway of CSCs and change their abilities. In our study, the results of CSC confirmation test such as specific surface CD markers and ability to form colonospheres was indicated the HT-29 cells as CSC-CRC. To increase the effectiveness of Silibinin, and also, to evaluate therapeutic intentions on HT29 cancer stem-like cells, we encapsulated Silibinin in polymersome nanoparticle and validated the antiproliferative and apoptotic activities of this new patent by MTT assay, AnnexinV/PI method, cell cycle analysis and DAPI staining. Furthermore, the efficacy of drug on Multicellular Tumor Spheroid (MCTS) and single cell suspension was showed that SPN had succeed to decrees the expression level of CSC CD markers compared with control group. Follow by using miRNAs as a novel and minus invasive expertise for prognostic, RT-qPCR confirmed that SPNs can repress oncogenic miRNAs such as miR-221 and miR222. Silibinin encapsulated in Polymersome Nanoparticles (SPNs) can also enhance the expression of tumor suppressor miR-34a and some of its proapoptotic target genes such as P53, BAX, CASP9, CASP3, and CASP8. Our results suggested that SPNs can be recognized as a new stimulant factor to direct the HT-29 cancer cells toward apoptosis pathways thorough modify expression of some miRNAs and their apoptotic target genes directly and/or indirectly.

\section{Introduction}

Colorectal cancer (CRC) is the third common malignancy and the second cause of death related to cancer which represented in men and women aged over 65 . However, due to increasing risk factors in recent decades such as obesity, bad nutritional habits, smoking and etc., frequency of disease has expanded in younger peoples [1]. In addition to physical, environmental aspects and also, genetic factors also play a significant role resulting in cancer. One of these genetic factors is miRNAs[2]. Many studies have indicated that dysregulation of small noncoding RNAs which are responsible for correct genes expression, can lead to irregular cellular behavior and bringing cancerousness [3][4]. One of these RNAs that called micro RNAs (miRNAs) have a validated role in cancer emersion. According to previous studies on relationship between miRNAs, tumorigenesis and their effect on CRC, the connection between altered miRNAs expression and caner progression was confirmed [5].These small RNAs inhibits genes expression by binding to 3 'noncoding region of their targets [6]. In silico analysis showed that miRNAs such as miR34a, miR-221 and miR-222, can target apoptotic genes such as TP53, BAX, CASP9, CASP3 and CASP8.

Due to the importance of cancer in life quality, with more studies on CRC, the heterogenous population cells were found with specific surface CD markers than common CRC cells such as CD44, CD24, epCAM, ALDH1, and CD133 [7][8][9]. These exclusive cells, called Cancer Stem Cells (CSCs), have individual features and responsible for self-renewal, produce differentiated cancer cells, initiate tumor growth, lost regulated proliferation, and etc. [1]. Another particular ability of CRC-CSC is the spontaneous 
accumulation of cancer cells in floating spheroid form (known as colonospheres) in vitro[10]. These notable specifications causing chemotherapy drug resistant of CSCs as well as cancer recurrence, such a way that 15 to 30 percent of patient have has recurrence of CRC within 2 to 5 years. Therefore, finding the new drug strategy to overcome the CSC can provide a hopeful prospect to have a normal life for cancer patients[11][12].

Nowadays, one of the most current treatment is chemotherapy, that recommended before or after surgery [13][14]. due to many side effects of chemotherapies, researcher try to find new benefit and without adverse effect strategies such as native drugs (herbals)[15]. Using of natural drugs has a long history and can be suggested as a candidate for cancer therapy [16][17]. Silibinin is a polyphonic flavonoid which has widely properties such as hepatoprotective activity, antioxidant, immunomodulatory, antiviral properties and anticancer.[18][19]. In addition, over the last decades, it has been demonstrated that Silibinin has capability to arrest the cell cycle, inhibit the DNA synthesis and cell division, activate the caspase cascade and apoptotic cell death, consequently. Despite all the specifications, Silibinin had deficiency in absorption by simple diffusion to cell. This complications cause to low bioavailability and poor cellular uptake of drug [20]. To overcome this problem and release additional amount on drug into the cells, researchers have used nano-carriers as a solution

Nowadays, different nano-carrier with individual features are applied such as, liposomes [21], dendrimers [22], micelles [23], nano emulsions [24] and polymersomes [25]. Polymersomes are a group of selfassembling polymers that are highly flexible, rather stable than liposomes and have long-time blood circulation [26]. So, this is compatible to maintenance of persistent drug concentration in the blood for a long time, with no applying to further doses. Also, with the various compounds which can be loaded in polymersomes, it will have a several capabilities in many applications in nanomedicine[27]. Thus, many lipophilic anticancer drugs, amphiphilic dyes, transgenes and membrane protein could be assembling within this nano-carrier without changing their activity. These advantages of polymersome, make it as a one of the remarkable supramolecular structure for numerous applications in nanomedicine and nanobiology[28] [25].

The goal of this study was to investigation the effect of Silibinin-loaded polymersome nanoparticle (SPN), as a new synthetic agent with nano-drug delivery strategy, on HT-29 cell line. We evaluated this new fortified drug for assessment of its effectiveness on CSC characteristics including surface CD markers and colonosphere forming. Furthermore, the effect of SPN on cell cytotoxicity and apoptosis pathways thorough adjustment the expression of miR-34a, miR-221 and miR-222, and also potential apoptotic pathways genes was examined scrutiny.

\section{Material And Methods}

\subsection{Materials}

Silibinin(2,3-Dihydro-3-(4-hydroxy-3-methoxyphenyl)-2(hydroxymethyl)-6-(3,5,7-trihydroxy-4oxobenzopyran-2-yl) benzo dioxin) was purchased from Sigma-Aldrich Co. (Schnelldorf, Germany) with 
purity of $\geq 98 \%$ (MW:482.44). All materials for the preparation of nanocarrier including oleoyl chloride and polyethylene glycol (400 KD) were purchased from Sigma-Aldrich (St Louis, MO, USA) and triethyl amine and chloroform were both purchased from EMD Millipore (Billerica, MA, USA). 40,6-diamidino-2phenylindole (DAPI) was purchase from Sigma-Aldrich Co. (Saint Quentin, France). All of the conjugated monoclonal antibody for CD133, CD24 and CD44 surface markers were purchased from (Invitrogen, Carlsbad, CA, USA).

\subsection{Preparation of Silibinin encapsulated in nanoparticle}

In the first stage, oleoyl chloride $(3.01 \mathrm{~g}, 0.01 \mathrm{~mol})$ and poly ethylene glycol $\mathrm{H}_{400}(20 \mathrm{~g}, 0.01 \mathrm{~mol})$ were mixed and in the solvent of triethyl amine $(1.2 \mathrm{~g}, 0.012 \mathrm{~mol})$ and chloroform were subjected to esterification reaction at $25^{\circ} \mathrm{C}$ for 4 hours. At the purification stage, the triethylammonium chloride salt was cleansed, the chloroform was evaporated and as a result, Polyethylene glycol 400 -oleate $\left(\mathrm{PEG}_{400}-\mathrm{OA}\right)$ was obtained. In order to use the $\mathrm{PEG}_{400}-\mathrm{OA}$ as a nanocarrier in preparation of Nanoparticles, $300 \mathrm{mg}$ of $\mathrm{PEG}_{400}-\mathrm{OA}$ and different concentration of Silibinin were dissolved in acetone solution. After that, the acetone was evaporated and the prepared product with different weight/weight ratios of Sil/ $\mathrm{PEG}_{400}-\mathrm{OA}$ (1:4 to $1: 30$ ) was stored at $4^{\circ} \mathrm{C}$ in a light-protected condition. Encapsulation Efficiency, drug loading of nanoparticle and also appropriate verification tests such as DLS, Zeta potential, AFM, TEM, SEM, Stability test was done to determinate the physical and chemical characterization including size, shape, zeta potential, morphology, stability, etc. [29]

\subsection{In vitro study}

\subsubsection{Cell culture study}

HT-29 cell line (Human Colorectal Adenocarcinoma Cell Line) was purchased from the National Cell Bank of Iran (NCBI, Pasteur Institute, Tehran, Iran) and cultured in DMEM medium supplemented with $10 \%$ FBS and $1 \% \mathrm{~L}$-glutamine at $37^{\circ} \mathrm{C}$ in a $5 \% \mathrm{CO} 2$ humidified atmosphere. All chemicals for cell culture were purchased from GIBCO (Gaithersburg, MD, USA).

\subsubsection{Determination of cell viability (MTT assay)}

MTT (3-[4,5-dimethylthiazol-2-yl]2,5-iphenyltetrazolium bromide) assay was used to evaluate the effect of Silibinin encapsulated in polymersome nanoparticles (SPNs) on proliferation and viability of HT-29 cell lines. According to the manufacturer's instructions (Sigma-Aldrich, USA), After $24 \mathrm{~h}$ of the HT-29 cells culture in a 96 -well plate $\left(1 \times 10^{4}\right.$ cells/well), the cells were treated by the serial concentrations of SPNs $(0$ to $200 \mu \mathrm{g} / \mathrm{ml}$ ) for $16,18,20,22,24,48$, and $72 \mathrm{~h}$. Afterwards, cells were washed with PBS, and $100 \mu \mathrm{L}$ of fresh medium containing $10 \mu \mathrm{L}$ of MTT $(5 \mathrm{mg} / \mathrm{ml})$ was added to each well and incubated for $3 \mathrm{~h}$ at $37^{\circ} \mathrm{C}$ in a $5 \% \mathrm{CO} 2$ humidified atmosphere. Finally, $100 \mu \mathrm{L}$ of dimethyl sulfoxide solution (DMSO) was added to each well, and Percent of cell survival was defined as the relative absorbance of treated cells versus control groups at 540nm (ELx800, BioTek, USA). As a results, the half maximal inhibitory concentration 
(IC50) of SPNs on HT-29 cell lines was determined by statistical analysis. Each experiment was carried out in triplicate and repeated at least three times.

\subsubsection{Apoptosis assay}

For apoptosis analysis, flow cytometry assays was carried out with using Annexin V-FITC kits (Miltenyi Biotech, Germany). According to the manufacturer's manual, $14,28,40$, and $50 \mu \mathrm{g} / \mathrm{ml}$ of SPNs was effected on $1 \times 10^{4}$ cells/well for $24 \mathrm{~h}$. After washing twice with binding buffer, $10 \mu \mathrm{L}$ of Annexin V-FITC was added and cells were incubated for $15 \mathrm{~min}$ in dark place. After washing the cells with $1 \mathrm{ml}$ of binding buffer for two times, stained cells centrifuged and cell pellet was resuspended in $500 \mu \mathrm{L}$ of binding buffer. Finally, $5 \mu \mathrm{L}$ of PI solution was added immediately prior to analysis by flow cytometry (BD FACS Calibur; BD Biosciences, San Jose, CA, USA). The experiments were repeated three times.

\subsubsection{Apoptosis detection by DAPI staining}

40',6-diamidino-2-phenylindole (DAPI) staining was used for assessment of HT-29 apoptotic cells with/without SPNs treatment. For this purpose, the cells were treated with SPNs at IC50 concentration $(28 \mu \mathrm{g} / \mathrm{ml})$ and incubation for $24 \mathrm{~h}, 48 \mathrm{~h}$, and $72 \mathrm{~h}$. Afterward, the cells were fixed with $4 \%$ paraformaldehyde, and stained using DAPI in PBS $(2.5 \mu \mathrm{g} / \mathrm{ml})$ for $15 \mathrm{sec}$ at $20^{\circ} \mathrm{C}$ in a dark condition. Finally, the stained cells were washed once with PBS, and the changes in SPNs treated cells were identified at 10-fold magnification using Nikon Eclipse-TE2000-S inverted microscopy compared with untreated cells.

\subsubsection{Cell cycle analysis}

After $24 \mathrm{~h}$ of induction of similar SPNs concentration with apoptosis assay, treated and control cells were washed with cold PBS and fixed in cold $70 \%$ ethanol at $4^{\circ} \mathrm{C}$ for $2 \mathrm{~h}$. Afterwards, $500 \mu \mathrm{L}$ PBS with $50 \mu \mathrm{L}$ RNase $(100 \mu \mathrm{g} / \mathrm{ml})$ was added to the fixed cells incubated at RT for $30 \mathrm{~min}$. Finally, PI $(50 \mu \mathrm{g} / \mathrm{ml})$ was added for cellular DNA staining, and after $30 \mathrm{~min}$, the cell cycle was analyzed by a flow cytometry instrument (BD FACS Calibur; BD Biosciences, San Jose, CA, USA).

\subsection{Cancer Stem Cell marker assay}

For sample preparation, $1 \times 10^{6}$ cells were centrifuged at $300 \mathrm{~g}$ for $5 \mathrm{~m}$. cell pellet was resuspended in $100 \mu \mathrm{L}$ of PBS containing $3 \%$ BSA (Sigma, St. Louis, MO) and incubated with an appropriate concentration of conjugated monoclonal antibody for CD133 PE (Phycoerythrin), CD24 APC (Allophycocyanin) and CD44 FITC (Fluorescein isothiocyanate) surface markers. After $1 \mathrm{~h}$ at $4^{\circ} \mathrm{C}$, the final volume of sample was adjusted to $1000 \mu \mathrm{L}$ with PBS and centrifuged at $300 \mathrm{~g}$ for $5 \mathrm{~m}$ at $4^{\circ} \mathrm{C}$. Finally, supernatant was removed, cell pellet was fixed by adding $500 \mu \mathrm{L}$ of $1 \%$ cold paraformaldehyde (Sigma, St. Louis, MO) and the sample was analyzed by flowcytometry instrument (BD FACS Calibur; BD Biosciences, San Jose, CA, USA).

\subsection{Preparation of Multicellular Tumor Spheroids}


Preparation of Multicellular Tumor Spheroids (MCTSs) are based on superiority of intracellular adhesive forces toward exogenous extracellular matrix such as cell culture flask. This advantage leads to promotion of cell-cell contact and forming spherical cancer structure such as tumor materials. For this purpose, hanging drop method was used according to the authors manual [30]. Briefly, 15 to 20 drops of harvested cells up to $30 \mu \mathrm{L}$ containing $0.5 \times 10^{6} \mathrm{cells} / \mathrm{ml}$ were deposited on a $10 \mathrm{~cm}$ dish lid. Following to inversion of the tray over the petri dish with has $10 \mathrm{ml}$ of PBS and incubation at $37^{\circ} \mathrm{C}$ for 3 to 10 days, cells were accumulated and gradually appeared in the form of single MCTS. As a result, a large amount of sphere forming cancer cells were obtained and incubated in untreated 6 well plates at $37^{\circ} \mathrm{C}$ for more experiments.

\subsection{Qualitative model response to drug treatment}

The effect of drug treatment on 3-dimentional culture was explored by comparing two difference cell culture models. The first model is single cell suspension within DMEM and the second model, a multicellular spheroid of approximately $10^{6}$ cells. For this purpose, single cell suspension and multicellular spheroid cells were exposed to $28 \mu \mathrm{g} / \mathrm{ml}$ of SPNs and after $24 \mathrm{~h}$, were analyzed by flowcytometry instrument (BD FACS Calibur; BD Biosciences, San Jose, CA, USA) for evaluation of desired CSC surface markers.

\subsection{RNA isolation and RT-qPCR analysis of miRNA expression}

RNA isolation and cDNA synthesis were performed using iNtRON kit (iNtRON Biotechnology, Korea) and BON-miR high sensitivity miRNA 1st-Strand cDNA synthesis Kit (Stem cell Technology Research Center, Tehran, Iran), respectively. Briefly, with using poly (A) polymerase at $37^{\circ} \mathrm{C}$, poly (A) tail was added to miRNAs during 30 min. After RNA poly(A) tail was mixed with BON-RT adaptor (primer,10 $\mu \mathrm{M}$ ) over 5 min incubation at $75^{\circ} \mathrm{C}$, RT enzyme, dNTPs and RT buffer were added and cDNA was synthesized during $25^{\circ} \mathrm{C}$ for $10 \mathrm{~min}$, at $42^{\circ} \mathrm{C}$ for $60 \mathrm{~min}$ and at $85^{\circ} \mathrm{C}$ for $5 \mathrm{~min}$. SYBR®Premix Ex TaqTM II (Takara Bio, Shiga, Japan) in Applied Biosystems StepOne ${ }^{\mathrm{TM}}$ instrument (Applied Biosystems, Foster City, USA) was used to Quantitative Real Time PCR(QRT-PCR) during $95^{\circ} \mathrm{C}$ for 30 seconds, followed by 40 cycles at $95^{\circ} \mathrm{C}$ for 3seconds and $60^{\circ} \mathrm{C}$ for 30 seconds.

$2^{-\Delta \Delta C t}$ method was applied to evaluation the expression level of each miRNA with SNORD 47 (U47) as the internal control. The primers were purchased from Stem cell Technology Research Center, Tehran, Iran and All reactions were performed in triplicate.

\subsection{Prediction of SPNs-inducing signaling pathways through miRNAs targeting genes}

The potential targets of miR-34a, miR-221 and miR-222 in two apoptotic pathways were predicted with Insilico analysis according to several algorithms such as TargetScan and miRWalk. These algorithms was supposed several parameters such as complementary sites of miRNAs in 3'-UTR of different mRNAs and the minimum binding energies to determine thermodynamically stability of miRNA-mRNA bindings [31] and predict potential targets of miRNAs. 


\subsection{Quantitative RT-PCR analyses of potential target genes}

The level of miR-34a, miR-221 and miR-222 targets expression in apoptotic pathways was evaluated with RT-qPCR. For this purpose, PrimeScript ${ }^{\mathrm{TM}} \mathrm{RT}$ reagent Kit (TaKara Bio) was used for cDNA synthesis and RT-qPCR was carried out using SYBR ${ }^{\circledR}$ Premix ExTaqTM II (Takara Bio, Shiga, Japan) in Applied Biosystems StepOneTM instrument (Applied Biosystems, Foster City, USA). The applied primers of apoptotic genes including TP53, BCL2, BAX, CASP9, CASP8 and CASP3 were obtained from Stem Cell Technology Research Center (Tehran, Iran) (Table 1). $2^{-\triangle \Delta C t}$ method was performed for assessment of potential targets relative expression, and the HPRT1 gene was used as the internal control gene.

\subsection{Statistical analysis}

All Statistical analysis was accomplished with Prism ${ }^{\circledR} 7$ software (GraphPad Software, Inc, La Jolla, CA, USA). Data were analyzed using one-way ANOVA followed by Newman-Keuls multiple comparison test or Student's t-test. A P-value of 0.05 was used to identify statistical significance. All Results were expressed as the mean $\pm S D$ and each experiment was repeated at least three times independently.

\section{Results}

\subsection{Effect of SPNs on HT29 cells proliferation}

HT-29 cells were treated with different concentrations $(0,5,12.5,25,40,45,50,70,85,100,150$ and 200 $\mu \mathrm{g} / \mathrm{ml}$ ) of SPNs during 16 to $72 \mathrm{~h}$. MTT assay analysis showed that SPNs inhibited the cell proliferation in a dose/time-dependent manner. The half maximal inhibitory concentration (IC50) of SPNs was $28.13 \pm 0.78 \mu \mathrm{g} / \mathrm{ml}$ after $24 \mathrm{~h}$ of treatment. In addition, our analysis declared that there is no significant reduction after 20 to $72 \mathrm{~h}$ (Fig.1).

\subsection{Apoptosis induction by SPNs}

Apoptosis induction in HT-29 cancer cells with $14 \mu \mathrm{g} / \mathrm{ml}, 28 \mu \mathrm{g} / \mathrm{ml}, 40 \mu \mathrm{g} / \mathrm{ml}$ and $50 \mu \mathrm{g} / \mathrm{ml}$ of SPNs was evaluated by the flow cytometry at three different times. After $24 \mathrm{~h}$ of treatments, the population of late apoptotic cells (Annexin $\mathrm{V}^{+} / \mathrm{PI}^{+}$) were increased significantly to $25.5 \%$ in cells treated with SPNs at IC50 $(28 \mu \mathrm{g} / \mathrm{ml})$ compared to untreated cells $(2.26 \%)$. Likewise, the more accurate study of apoptotic assay showed that the apoptotic percentage of treated cells were regularly increased in a dose-dependent manner comparable to control cells (Fig.2).

\subsection{Apoptosis detection by DAPI staining}

Our DAPI staining analysis showed the significant decrease of stained nuclei in HT29 cells after treatment with SPNs in IC50 concentration compared to control group. The results also evaluated that the treated cells with SPNs were lost their numbers during the time within 24 to $72 \mathrm{~h}$ (Fig.3).

\section{4 cell cycle analysis}


The flow cytometric analysis showed that the percentage of cells in sub-G1 phase increased with the increase of SPNs concentration. Flow cytometric analysis showed that the percentage of cells in the subG1 phase changed from $7.71 \%$ in the control to 11.32 at $28 \mu \mathrm{g} / \mathrm{ml}$ (IC50) of SPNs-treated cells after $24 \mathrm{hr}$. In addition, a significant decrease $(P<0.05$ to $P<0.01)$ was observed in the cell population in the G0/G1 phase from $66.83 \%$ in the control cells to $60.38 \%, 59.84 \%$ and $50.69 \%$ at 14,28 and $40 \mu \mathrm{g} / \mathrm{ml}$ of SPNstreated cells, respectively (Fig.4A).

Compare to the control group, the amount of HT-29 cancer cells after treatment with SPNs indicated the significant arrest of cancer cells in G2/M phase of the cell cycle after $24 \mathrm{~h}$. Analyzed data imply that increasing drug concentration in arrested phase cause to increase accumulation of cancer cells in which $10.48 \%$ at IC50 dose compare to an un-treated one in 5.07\%. (Fig.4B)

\subsection{Cancer stem-like cell characterization in HT29 cell line}

The HT29 cancer cell line was evaluated for expression level of stem cell surface markers such as CD133, CD24 and CD44. Applied flow cytometry revealed that $86.4 \% \pm 2.75$ and $77.4 \% \pm 2.12$ of HT29 cancer cells were $\mathrm{CD} 44^{+} / \mathrm{CD}_{13} 3^{+}$and $\mathrm{CD} 44^{+} / \mathrm{CD} 24^{+}$respectively (Fig.5). In addition, observations from hanging drop assay showed that HT29 spheroid forming capacity was become visible after 3 days of incubation in $37^{\circ} \mathrm{C}$ and MCTSs were condensed after 10 days (Fig.6).

\subsection{Qualitative model response to drug treatment}

The cancerous cells drug response was evaluated by comparing two different models of HT29 cancer cells including single cell suspension and multicellular spheroid forms. The results showed that treatment of single cell suspension with SPNs was much more effective than multicellular spheroid form. Flow cytometry analysis identified that $70.3 \pm 4.03 \%$ and $66.7 \pm 3.18 \%$ of multicellular spheroids were $\mathrm{CD} 44^{+}$/ $\mathrm{CD} 133^{+}$and $\mathrm{CD} 44^{+} / \mathrm{CD} 24^{+}$respectively whereas this CSCs marker were much lower in single cell type $\left(9.23 \%\right.$ of $\mathrm{CD} 44^{+}, 19.9 \%$ of $\mathrm{CD} 133^{+}$and $7.42 \%$ of $\left.\mathrm{CD} 24^{+}\right)$. It is worth noting that in both comparing models, the surface markers were less than untreated ones (Fig.7).

\subsection{Up and down regulation of miRNAs associated with cancerous pathways}

Q-RT-PCR analysis showed that in SPNs treated cells, miR-34a were significantly upregulated $(2.22 \pm 0.07$ folds) and miR-221 and miR-222 were significantly downregulated $(0.61 \pm 0.3$ and $0.52 \pm 0.02$ folds, respectively) (Fig.8-A).

\subsection{Potential targets of miRNAs in apoptotic pathways}

In Silico analysis predicted several potential targets of desired miRNAs at intrinsic (mitochondrial) and extrinsic pathway of apoptosis including TP53, BAX, CASP3, CASP8 and CASP9 (Table 2).

\subsection{Upregulation of potential target genes in apoptotic pathways}


RT-qPCR analysis revealed that some genes involved in intrinsic and extrinsic pathways of apoptosis including TP53, BAX, CASP9, CASP3 and CASP 8 were significantly upregulated $>2$ folds in SPNs treated HT29 cells compared to untreated cells (Fig.8-B). Furthermore, the decrease in expression of antiapoptotic $B C L 2$ gene was also observed in treated cells $(0.23 \pm 0.10$ fold $)$.

\section{Discussion}

Colorectal cancer (CRC) has the most common malignant gastrointestinal tumor cancer, and is the second most common cause of death related to cancer in box sex, as well as the third most common kind of cancer in oncologic pathology sampling[1][32]. One of the most challenging matter in cancer treatment is the elimination of Cancer Stem Cells (CSCs) because of their ability to relapse of cancer after treatment and drug resistance[33].

Recent studies showed that Silibinin, an herbal extract from milk thistle plant, is recognized as a potential cancer protective drug and also can target the signaling pathways in CSCs and conducted these cells to differentiate and lose their properties [34][34].

Chapla Agarwal was reported that at $50-100 \mu \mathrm{g} / \mathrm{ml}$ of Silibinin, $8-39 \%, 35-75 \%$ and $57-91 \%$ of HT-29 cell growth was inhibited after 24,48 and $72 \mathrm{~h}$, respectively[35]. Also, the cell growth inhibition doses of Silibinin on SW480 and SW620 colorectal cancer cell line was evaluated by Henriette Kauntz and observed that it was $40-100 \mu \mathrm{g} / \mathrm{ml}$ within 8 days [36]. Shanaya Patel et.al also showed that Silibinin inhibited cell proliferation of HCT116-CD44+ subpopulation of colon cancer stem cells at $\otimes 120 \mu \mathrm{g} / \mathrm{ml}$ [37]. In our previous study, we synthetized a polymersome nanocarrier that due to suitable properties(appropriate size, narrow size distribution, higher Encapsulation Efficiency (EE) and Drug Loading (DL)) [29] we again used in this study. In this study, Silibinin in polymersome nanoparticles had cytotoxicity effects in lower dose $(\mathrm{IC} 50=28 \mu \mathrm{g} / \mathrm{ml})$ during $24 \mathrm{~h}$ relative to previous studies. It is considerable that SPNs can inhibit proliferation in concentration $45.06 \mu \mathrm{g} / \mathrm{ml}$ in MDA-MB-231 breast cancer cells after 24h [29], while in this study, lower concentration of SPNs effected on proliferation inhibition. Results showed that Silibinin could not only be more effective in the drug delivery system with this new nano-structure, but also at lower dose in some cancer areas such as gastrointestinal tract could be more effective than breast tissue.

apoptosis Induction by Silibinin ( $\$ 144 \mu \mathrm{g} / \mathrm{ml}$ ) for $48-72 \mathrm{~h}$ on SW480 and SW620 colorectal cancer cell lines was reported (21\%-31\% and $23 \%-40 \%$ late apoptosis, respectively) [36]. The total percentage of apoptosis in colorectal cancer cell line HCT116-CD44+ after induction of $120 \mu \mathrm{g} / \mathrm{ml}$ of Silibinin was $11.6 \%$ and $29.5 \%$ at 24 and $48 \mathrm{~h}$, respectively [37]. Our analysis revealed that late and total apoptosis percentage increased significantly to $25.5 \%$ and $32.36 \%$ in SPNs treated cells $(28 \mu \mathrm{g} / \mathrm{ml})$ only after $24 \mathrm{~h}$. It's worth noting that as it observed in DAPI staining, the apoptotic percentage of treated cells were regularly increased in a dose-dependent manner. Then, nano structures in our study increased apoptosis induction by Silibinin on cancer cells in lower dose and time. 
Previous study on human colon carcinoma HT-29 cells showed that Silibinin can be induced cell cycle arrest in $\mathrm{G0} / \mathrm{G} 1$ phases at $50 \mu \mathrm{g} / \mathrm{ml}$, and also caused to G2/M arrest with higher dose $(100 \mu \mathrm{g} / \mathrm{ml})$ and longer treatment time [38]. Further studies on colon cancer HT-29 and HCT-116 cell line also indicated on G0/G1 and G2/M arrest in cell cycle progression with Silibinin in dose/time dependent manner [39]. Our research showed that SPN can be considered as an effective cell cycle blocker in two check point in lower dose. Data analysis indicated that SPN can strongly induced cell cycle arrest in G2/M and proportionally in $\mathrm{S}$ in $28 \mu \mathrm{g} / \mathrm{ml}$ at $24 \mathrm{~h}$ (IC50 dose). This finding shows the greater performance of encapsulated Silibinin to regulate the cell mitosis and apoptosis death, respectively.

In this study, we intended to evaluation of our HT29 CRC cell line in terms of having CSC characteristics including specific surface CD markers and ability to form colonospheres. Our flowcytometry analysis showed that HT29 CRC cell line have $77.4 \%$ of $\mathrm{CD} 44^{+} / \mathrm{CD} 24^{+}$and $86.4 \%$ of $\mathrm{CD} 44^{+} / \mathrm{CD} 133^{+}$as well as forming colonospheres. Therefore, it seems that we can consider the HT29 cancer cell line as CSC-CRC.

The first assessment of the SPN effect on HT29 Cancer Stem-like Cells is to evaluate the ability of drug to reduce the CSC CD markers. Previous studies showed that Silibinin can significantly decrease the percentage of colorectal CSC by targeting their Specific CD markers. it also indicated that Silibinin can effect on colonosphere forming of CSCs by reducing their specific markers [40][37][41].

Follow this, for more accurate evaluation of SPN effect on CSC, the efficacy of drug was calculated in two difference cell culture models including Multicellular Tumor Spheroid (MCTS) and single cell suspension. The result was indicated that SPN had succeeded to decrees the expression level of CSC CD markers compared with control group. The percentage of $\mathrm{CD} 44^{+} / \mathrm{CD} 24^{+}$and $\mathrm{CD} 44^{+} / \mathrm{CD} 133^{+}$in $\mathrm{MCTS}$ after treatment with SPN decreased to $10.7 \%$ and $16.1 \%$, respectively. As the same way, the percentage of $\mathrm{CD} 44^{+}, \mathrm{CD} 24^{+}$and $\mathrm{CD} 133^{+}$in single cell suspension with a great extent reduced were changed to $9.23 \%$, $7.42 \%$ and $19.9 \%$, respectively. However, due to lower accessibility of SPNs to center of mass in tumor spheroids (in MCTS models) after 24h, decrease of surface markers were less than single cells model. Nonetheless, after 72h, most cells in MCTS was lost. Therefore, using SPNs can effective on removal colorectal CSCs. Our finding suggested that the use of polymersome nanoparticles can increas anti-stem less cancerous properties of Silibinin. This higher performance of Silibinin as an anti-cancer stem cell agent is due to its new and outperform nanostructure.

Previous investigation showed that one of the influencer miRNAs in various cancers[42] as well as Colorectal CSCs is miR-34a. This miRNA is known as a tumor suppressor and so it has been made clear that miR34a may decrease in cancerous stem cells. [43][44][45]. The result of our study showed that after the treatment of HT29 Cancer Stem-like Cells with SPNs, the expression of miR34a increased compared to control cells. This data suggested that the SPNs may have the ability to inhibit proliferation of the colorectal CSCs by mediating miR-34a.

The two other miRNAs that have been extensively researched for the past nine years on their association with Colorectal cancer is miR-221 and miR-222. In 2014 scientists also showed that miR-221 and mir-222 
can activate NFkB and STAT3 and increase expression of both in CRC[46].

From the point of view of the results, it seems that SPN can direct the HT-29 cancer cells toward apoptosis pathways thorough modification of mentioned miRNAs expression.

From another perspective, previous studies showed that Silibinin can accelerate the treatment of CRCCSC by reducing specific CD markers[47][48].

According to mentioned studies and also the results of our research based on reducing CD markers in treated-HT-29 Cancer Stem-like Cells, it can be suggested that SPN can perform its therapeutic effect on the CRC-CSCs by modulate the miRNAs expression and decrease the CSC specific CD markers.

Since that miRNA's deregulation leads to dysfunction of genes, using in silico analysis, the predicted potential apoptotic pathways genes that can be controlled by miR-34a, miR-221 and miR-222 were selected.

The result of our study showed that after the treatment of HT29 Cancer Stem-like Cells with SPNs, the expression of miR34a increased compared to control cells. This data suggested that the SPNs may have the ability to inhibit proliferation of the colorectal CSCs by mediating miR-34a.

Our bioinformatic analysis showed that miR34a can target apoptotic genes such as TP53, BAX, CASP9, CASP3 and CASP8. In previous studies, our predictions validated as miR-34a targets Previous studies validated that expression of miR34a was related in regulation of intrinsic apoptosis pathway genes such as TP53 [49], BAX [50], CASP9 [51], , and extrinsic apoptosis pathway genes such as CASP3 and CASP8 [51]. In addition, the relationship between miR221/222 and expression of mentioned apoptosis pathway genes were predicted by in silico analysis.

As a consequence, quantitative analysis revealed that $P 53, B A X, C A S P 9, C A S P 3$ and $C A S P 8$ were upregulated after treatment of HT29 Cancer Stem-like Cells with SPNs. On the other hand, our study also showed that $B c / 2$ becomes downregulated after SPNs induction. According to validated and predicted target genes of miR34a, miR-221 and mir-222, it seems that modifying of the expression of apoptotic pathway genes may be cause of change in expression of desired miRNAs by SPNs.

\section{Conclusion}

Due to the results, HT-29 cancer cell line can be notice as CSC-CRC and the apoptotic percentage of treated cells after treatment with SPNs were regularly increased. Moreover, the results can suggest that SPNs with a new, functional and unique structure can be identified as a Stimulus to drive HT-29 cancer cells to apoptosis. Our nano- effective structure does its responsibility toward apoptosis pathways thorough modification of miR34a, miR-221 and mir-222, expression. This new nano-Silibinin can be also directly and/or indirectly adjust the expression of intrinsic/extrinsic apoptotic pathways genes. 


\section{Declarations}

Acknowledgements:

We appreciate the valued faculty members and colleagues of Stem Cell Technology Research Center that contributes made this research possible.

\section{Funding statement:}

This research did not receive any specific grant from funding agencies in the public, commercial or notfor-profit sectors.

\section{Author contributions:}

The authors 'responsibilities were as follows: N.R., and F.N. contributed for conception and design of this article. S.H., S.P., N.R., and A.N.S. contributed for analysis and interpretation. S.H., and A.N.S. were involved in statistical analysis. S.H., N.R., and A.N.S. contributed in writing and provided critical revision for this article. S.H., S.P, A.N.S., F.N., and N.R. gave final approval for this article. All authors agree to be accountable for all aspects of the work

\section{Consent to publish:}

The Author confirms:

that the work described has not been published before (except in the form of an abstract or as part of a published lecture, review, or thesis);

that it is not under consideration for publication elsewhere; that its publication has been approved by all co-authors, if any;

that its publication has been approved (tacitly or explicitly) by the responsible authorities at the institution where the work is carried out

\section{Compliance with ethical standards:}

The article contains no research in which animals were used. Also, This Experiment involved no biological materials obtained from people, patient cohorts, and etc.

\section{References}

[1] B. Granados-Romero, Juan José, Valderrama-Treviño, Alan Isaac, Contreras-Flores, Ericka Hazzel, Barrera-Mera, M. Herrera Enríquez, K. Uriarte-Ruíz, and G. Ceballos-Villalba, Jesús Carlos, Estrada-Mata, Aranza Guadalupe, Alvarado Rodríguez, Cristopher Arauz-Peña, "Colorectal cancer: a review," Int. J. Res. Med. Sci., vol. 5, no. 11, p. 4667, 2017. 
[2] N. Afrang et al., "A critical role for miR-184 in the fate determination of oligodendrocytes," Stem Cell Res. Ther., vol. 10, no. 1, p. 112, Dec. 2019.

[3] B. A. Orang AV1, "MicroRNAs in colorectal cancer: from diagnosis to targeted therapy. - PubMed NCBI," Asian Pac J Cancer Prev. [Online]. Available: https://www.ncbi.nlm.nih.gov/pubmed/25227782. [Accessed: 04-May-2019].

[4] S. Pakizehkar, N. Ranji, A. Naderi Sohi, and M. Sadeghizadeh, "Curcumin loaded PEG 400 -OA nanoparticles: A suitable system to increase apoptosis, decrease migration, and deregulate miR125b/miR182 in MDA-MB-231 human breast cancer cells," Polym. Adv. Technol., Mar. 2020.

[5] T. Tsunoda, Y. Takashima, Y. Yoshida, and K. Doi, "Oncogenic KRAS regulates miR-200c and miR221/222 in a 3D-specific manner in colorectal cancer cells.," Anticancer Res., vol. 31, no. 7, pp. 2453-9, Jul. 2011.

[6] C. Y. Chu and T. M. Rana, "Small RNAs: Regulators and guardians of the genome," Journal of Cellular Physiology, vol. 213, no. 2. John Wiley \& Sons, Ltd, pp. 412-419, 01-Nov-2007.

[7] S. H. Sahlberg, D. Spiegelberg, B. Glimelius, B. Stenerlöw, and M. Nestor, “Evaluation of Cancer Stem Cell Markers CD133, CD44, CD24: Association with AKT Isoforms and Radiation Resistance in Colon Cancer Cells," PLoS One, vol. 9, no. 4, p. e94621, Apr. 2014.

[8] E. N. Garza-Treviño, S. L. Said-Fernández, and H. G. Martínez-Rodríguez, “Understanding the colon cancer stem cells and perspectives on treatment," Cancer Cell Int., vol. 15, no. 1, p. 2, 2015.

[9] A. Jaggupilli and E. Elkord, "Significance of CD44 and CD24 as Cancer Stem Cell Markers: An Enduring Ambiguity," Clin. Dev. Immunol., vol. 2012, pp. 1-11, May 2012.

[10] S. Shaheen, M. Ahmed, F. Lorenzi, and A. S. Nateri, "Spheroid-Formation (Colonosphere) Assay for in Vitro Assessment and Expansion of Stem Cells in Colon Cancer.," Stem Cell Rev., vol. 12, no. 4, pp. 492-9, 2016.

[11] S. R. Fatemi et al., "Recurrence and Five Year Survival in Colorectal Cancer Patients After Surgery," Iran. J. Cancer Prev., vol. 8, no. 4, Aug. 2015.

[12] N. T. Saleh, A. N. Sohi, E. Esmaeili, S. Karami, F. Soleimanifar, and N. Nasoohi, "Immobilized Lamininderived Peptide Can Enhance Expression of Stemness Markers in Mesenchymal Stem Cells," Biotechnol. Bioprocess Eng., vol. 24, no. 6, pp. 876-884, Nov. 2019.

[13] B. A. Chabner and T. G. Roberts, "Chemotherapy and the war on cancer," Nat. Rev. Cancer, vol. 5, no. 1, pp. 65-72, 2005.

[14] M. J. Munro, S. K. Wickremesekera, L. Peng, S. T. Tan, and T. Itinteang, "Cancer stem cells in colorectal cancer: A review," J. Clin. Pathol., vol. 71, no. 2, pp. 110-116, 2018. 
[15] L. P. M, B. P. K, and V. S. Kotakadi, "Herbal and Medicinal Plants Molecules Towards Treatment of Cancer: A Mini Review," vol. 2, no. 2, 2015.

[16] S.-Y. Yin, W.-C. Wei, F.-Y. Jian, and N.-S. Yang, "Therapeutic applications of herbal medicines for cancer patients.," Evid. Based. Complement. Alternat. Med., vol. 2013, p. 302426, 2013.

[17] A. G. Desai et al., "Medicinal plants and cancer chemoprevention.," Curr. Drug Metab., vol. 9, no. 7, pp. 581-91, Sep. 2008.

[18] H. Chang et al., "Silibinin Inhibits the Invasion and Migration of Renal Carcinoma 786-0 Cells In Vitro, Inhibits the Growth of Xenografts In Vivo and Enhances Chemosensitivity to 5-Fluorouracil and Paclitaxel," vol. 823, no. January, pp. 812-823, 2011.

[19] R. Lim, C. J. Morwood, G. Barker, M. Lappas, and P. Proost, "Effect of Silibinin in Reducing Inflammatory Pathways in In Vitro and In Vivo Models of Infection-Induced Preterm Birth," PLoS One., vol. 9, p. e92505, 2014.

[20] P. Kidd and K. Head, "A review of the bioavailability and clinical efficacy of milk thistle phytosome: A silybin-phosphatidylcholine complex (Siliphos)," Altern. Med. Rev., vol. 10, no. 3, pp. 193-203, 2005.

[21] P. P. Deshpande, S. Biswas, and V. P. Torchilin, "Current trends in the use of liposomes for tumor targeting.," Nanomedicine (Lond)., vol. 8, no. 9, pp. 1509-28, Sep. 2013.

[22] J. R. Baker, “Dendrimer-based nanoparticles for cancer therapy," Hematology, vol. 2009, no. 1, pp. 708-719, Jan. 2009.

[23] D. Keskin and A. Tezcaner, "Micelles As Delivery System for Cancer Treatment," Curr. Pharm. Des., vol. 23, no. 35, pp. 5230-5241, Jan. 2018.

[24] M. Amiji and S. Tiwari, "Nanoemulsion Formulations for Tumor-Targeted Delivery," in Nanotechnology for Cancer Therapy, CRC Press, 2006, pp. 723-739.

[25] X. Zhang and P. Zhang, "Polymersomes in Nanomedicine - A Review," Curr. Nanosci., vol. 13, no. 2, pp. 124-129, Feb. 2017.

[26] D. E. Discher et al., "Polymer vesicles.," Science, vol. 297, no. 5583, pp. 967-73, 2002.

[27] M. Ghavami-Lahiji, F. Shafiei, F. Najafi, and M. Erfan, "Drug-loaded polymeric films as a promising tool for the treatment of periodontitis," J. Drug Deliv. Sci. Technol., vol. 52, pp. 122-129, Aug. 2019.

[28] S. Pakizehkar, N. Ranji, A. N. Sohi, and M. Sadeghizadeh, "Polymersome-assisted delivery of curcumin: A suitable approach to decrease cancer stemness markers and regulate miRNAs expression in HT29 colorectal cancer cells," Polym. Adv. Technol., p. pat.4759, Nov. 2019. 
[29] S. Hossainzadeh, N. Ranji, A. Naderi Sohi, and F. Najafi, "Silibinin encapsulation in polymersome: A promising anticancer nanoparticle for inducing apoptosis and decreasing the expression level of miR125b/miR-182 in human breast cancer cells," J. Cell. Physiol., p. jcp.28795, May 2019.

[30] L. Weiswald, D. Bellet, and V. Dangles-marie, "Spherical Cancer Models in Tumor," NEO, vol. 17, no. 1, pp. 1-15, 2015.

[31] M. M. Zadeh, N. Motamed, N. Ranji, M. Majidi, and F. Falahi, "Silibinin-Induced Apoptosis and Downregulation of MicroRNA-21 and MicroRNA-155 in MCF-7 Human Breast Cancer Cells," J. Breast Cancer, vol. 19, no. 1, pp. 45-52, Mar. 2016.

[32] P. Vega, F. Valentín, and J. Cubiella, "Colorectal cancer diagnosis: Pitfalls and opportunities," World J. Gastrointest. Oncol., vol. 7, no. 12, p. 422, 2015.

[33] Y. Zhou, L. Xia, H. Wang, L. Oyang, M. Su, and Q. Liu, "Cancer stem cells in progression of colorectal cancer.," Oncotarget, vol. 9, no. 70, pp. 33403-33415, Sep. 2018.

[34] S. Kumar, K. Raina, C. Agarwal, and R. Agarwal, "Silibinin strongly inhibits the growth kinetics of colon cancer stem cell-enriched spheroids by modulating interleukin 4/6-mediated survival signals.," Oncotarget, vol. 5, no. 13, pp. 4972-89, Jul. 2014.

[35] C. Agarwal, R. P. Singh, S. Dhanalakshmi, and D. de Leeuw, "Silibinin upregulates the expression of cyclin-dependent kinase inhibitors and causes cell cycle arrest and apoptosis in human colon carcinoma HT-29 cells," Oncogene, vol. 22, no. 51, pp. 8271-8282, Nov. 2003.

[36] H. Kauntz, "Cellular and Molecular Targets of Silibinin , a Natural Flavonoid , in Colorectal Cancer Prevention and Therapy," Human health and pathology. Université de Strasbourg, Strasbourg, 2012.

[37] S. Patel, B. Waghela, and K. Shah, "Silibinin, A Natural Blend In Polytherapy Formulation For Targeting Cd44v6 Expressing Colon Cancer Stem Cells," Sci. Rep., vol. 8, no. 1, p. 16985, Dec. 2018.

[38] C. Agarwal, R. P. Singh, and S. Dhanalakshmi, "Silibinin upregulates the expression of cyclindependent kinase inhibitors and causes cell cycle arrest and apoptosis in human colon carcinoma HT-29 cells," Oncogene, vol. 22, no. 51, pp. 8271-8282, Nov. 2003.

[39] Yi-Xin Wang1, * H. C., Gang Jiang1, Tian-Bao Zhou2, and Hai Wu, "Silibinin inhibits proliferation, induces apoptosis and causes cell cycle arrest in human gastric cancer MGC803 cells via STAT3 pathway inhibition," Asian Pacific J. Cancer Prev. J Cancer Prev, vol. 15, no. 1516, pp. 6791-6798, 2014.

[40] R. Agarwal and C. Agarwal, "Abstract B32: Translational potential of a small-molecule silibinin in colorectal cancer: Targeting cancer stem cells and their inflammatory niche," in Precision Medicine/Targeted and Combination Therapies/Drug Resistance, 2018, vol. 24, no. 1 Supplement, pp. B32-B32. 
[41] Y.-C. Chang, C.-I. Jan, P. Chih-Yu, Lai Yu-Chi, H. Fang-Wei, and C. C. Yu, "Activation of microRNA-494targeting Bmi1 and ADAM10 by silibinin ablates cancer stemness and predicts favourable prognostic value in head and neck squamous cell carcinomas," Oncotarget, vol. 6, no. 27, pp. 24002-16, Sep. 2015.

[42] R. M, V. R, R. N, S. MH, M. M, and S. SM, "The Effect of Over-Expression of miR-20a on Cell Proliferation of Human T Cell Leukemia Cell Line," Clin. Lab., vol. 64, no. 10/2018, pp. 1641-1647, 2018.

[43] R. Rupaimoole and F. J. Slack, "A role for miR-34 in colon cancer stem cell homeostasis," Stem Cell Investig., vol. 3, no. December 2012, pp. 42-42, 2016.

[44] Y. Ma et al., "MicroRNA-34a Mediates the Autocrine Signaling of PAR2-Activating Proteinase and Its Role in Colonic Cancer Cell Proliferation," PLoS One, vol. 8, no. 8, p. e72383, Aug. 2013.

[45] C. LI et al., "miR-34a inhibits colon cancer proliferation and metastasis by inhibiting platelet-derived growth factor receptor a," Mol. Med. Rep., vol. 12, no. 5, pp. 7072-7078, Nov. 2015.

[46] S. Liu, X. Sun, M. Wang, and Y. Hou, "A microRNA 221- and 222-Mediated Feedback Loop Maintains Constitutive Activation of NFKB and STAT3 in Colorectal Cancer Cells," Gastroenterology, vol. 147, no. 4, pp. 847-859.e11, Oct. 2014.

[47] S. Kumar, K. Raina, C. Agarwal, and R. Agarwal, "Silibinin strongly inhibits the growth kinetics of colon cancer stem cell-enriched spheroids by modulating interleukin 4/6-mediated survival signals.," Oncotarget, vol. 5, no. 13, pp. 4972-89, Jul. 2014.

[48] C. Fanali et al., "Cancer stem cells in colorectal cancer from pathogenesis to therapy: controversies and perspectives.," World J. Gastroenterol., vol. 20, no. 4, pp. 923-42, Jan. 2014.

[49] F. Navarro and J. Lieberman, "miR-34 and p53: New Insights into a Complex Functional Relationship," PLoS One, vol. 10, no. 7, p. e0132767, Jul. 2015.

[50] N. Fan and J. Wang, "MicroRNA 34a contributes to virus-mediated apoptosis through binding to its target gene Bax in influenza A virus infection," Biomed. Pharmacother., vol. 83, pp. 1464-1470, Oct. 2016.

[51] R. A. Yacoub, I. O. Fawzy, and R. A. Assal, "miR-34a: Multiple Opposing Targets and One Destiny in Hepatocellular Carcinoma.," J. Clin. Transl. Hepatol., vol. 4, no. 4, pp. 300-305, Dec. 2016.

\section{Tables}

Table 1. Sequence of primers used for RT-qPCR analyses 


$\begin{array}{cc}\text { Genes and miRNAs } & \text { Oligo-sequences } \text { (5' }^{\prime} \mathbf{3}^{\prime} \text { ) } \\ \text { (-F/-R) } & \\ \text { P53 } & \text { GGAGTATTTGGATGACAGAAAC } \\ \text { P53 } & \text { GATTACCACTGGAGTCTTC } \\ \text { BAX } & \text { CAAACTGGTGCTCAAGGC } \\ \text { BAX } & \text { CACAAAGATGGTCACGGTC } \\ \text { CASP9 } & \text { AGGGTCGCTAATGCTGTTTCG } \\ \text { CASP9 } & \text { TCGTCAATCTGGAAGCTGCTAAG } \\ \text { BCL2 } & \text { GATAACGGAGGCTGGGATG } \\ \text { BCL2 } & \text { CAGGAGAAATCAAACAGAGGC } \\ \text { CASP3 } & \text { CACAGCACCTGGTTATTATTC } \\ \text { CASP3 } & \text { TTGTCGGCATACTGTTTCA } \\ \text { CASP8 } & \text { GGATGATGACATGAACCTGCTGGA } \\ \text { CASP8 } & \text { TTGTTGATTTGGGACAGACTCTT } \\ \text { HPRT1 } & \text { CCTGGCGTCGTGATTAGTG } \\ \text { HPRT1 } & \text { TCAGTCCTGTCCATAATTAGTCC } \\ \text { SNORD47 } & \text { ATCACTGTAAAACCGTTCCA } \\ \text { SNORD47 } & \text { GAGCAGGGTCCGAGGT } \\ \text { miR-34a } & \text { ATGGTGGCAGTGTCTTAGC } \\ \text { miR-34a } & \text { GAGCAGGGTCCGAGGT } \\ \text { miR-221 } & \text { ATTCAGGGCTACATTGTCTG } \\ \text { miR-221 } & \text { GAGCAGGGTCCGAGGT } \\ \text { miR-222 } & \text { ACGATGCCAGTTGAAGAAC } \\ \text { miR-222 } & \text { GAGCAGGGTCCGAGGT } \\ & \end{array}$

Note. P53-F/R: Tumor protein p53- Forward/Reverse; BAX-F/R: BCL2

Associated X- Forward/Reverse; CASP9-F/R: Caspase 9, apoptosis-related cysteine peptidase- Forward/Reverse; BCL2-F/R: BCL2, apoptosis regulator- Forward/Reverse; CASP3-F/R: Caspase 3, apoptosis-related cysteine peptidase- Forward/Reverse; CASP8F/R: Caspase 8, apoptosis-related cysteine peptidase- Forward/Reverse; HPRT1-F/R: Hypoxanthine PhosphoRibosyl Transferase1Forward/Reverse; SNORD47-F/R: small nucleolar RNA, C/D box 47 - Forward/Reverse; miR-34a/221/222-F/R: microRNA34a/221/222- Forward/Reverse.

Table 2. Some potential targets of miRNAs 


\begin{tabular}{|l|l|l|}
\hline miRNAs & Some Potential Target Genes & \multicolumn{1}{|c|}{ Genes Name } \\
\hline miR-34a & BIK & BCL2 Interacting Killer \\
& BCL2 & BCL2, apoptosis regulator \\
& PRAP1 & Proline rich acidic protein 1 \\
& BAD & BCL2 associated agonist of cell death \\
& APAF1 & Apoptotic peptidase activating factor 1 \\
& AVEN & Apoptosis and caspase activation inhibitor \\
& BAK1 & BCL2 antagonist/killer 1 \\
& DEDD & Death effector domain containing \\
& BID & BH3 interacting domain death agonist \\
\hline miR-221 & BAX & BCL2 associated X, apoptosis regulator \\
& NUDT3 & Nudix hydrolase 3 \\
& PARP1 & Poly (ADP-ribose) polymerase 1 \\
& CASP9 & Caspase 9, apoptosis-related cysteine peptidase \\
& CASP3 & Caspase 3, apoptosis-related cysteine peptidase \\
& CASP8 & Caspase 8, apoptosis-related cysteine peptidase \\
& PRR13 & proline rich 13 \\
& P53 & Tumor protein p53 \\
& CCNT1 & cyclin T1 \\
\hline miR-222 & E2F2 & E2F transcription factor 2 \\
& CASP9 & Caspase 9, apoptosis-related cysteine peptidase \\
& BNK2 & WNK lysine deficient protein kinase 2 \\
& P53 & BCL2 associated X, apoptosis regulator \\
& CASP3 & TGFA \\
& PCNA & Tumor protein p53 \\
& CASP8 & Caspase 3, apoptosis-related cysteine peptidase \\
& & transforming growth factor alpha \\
& & proliferating cell nuclear antigen \\
& Caspase 8, apoptosis-related cysteine peptidase \\
\end{tabular}

Note. miR-34a: microRNA-34a; miR-221: microRNA-221; miR-222: microRNA-222.

\section{Figures}




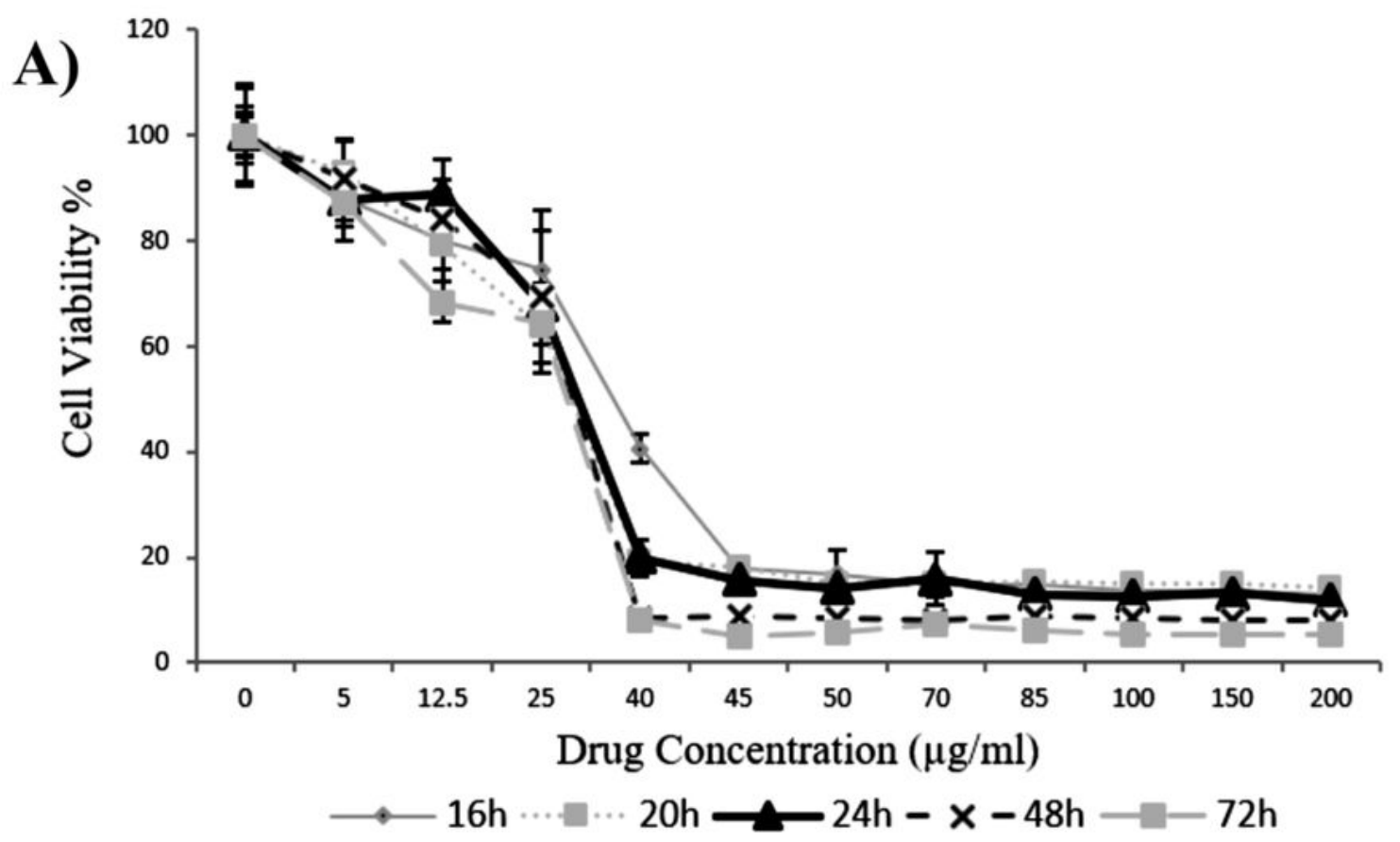

B)

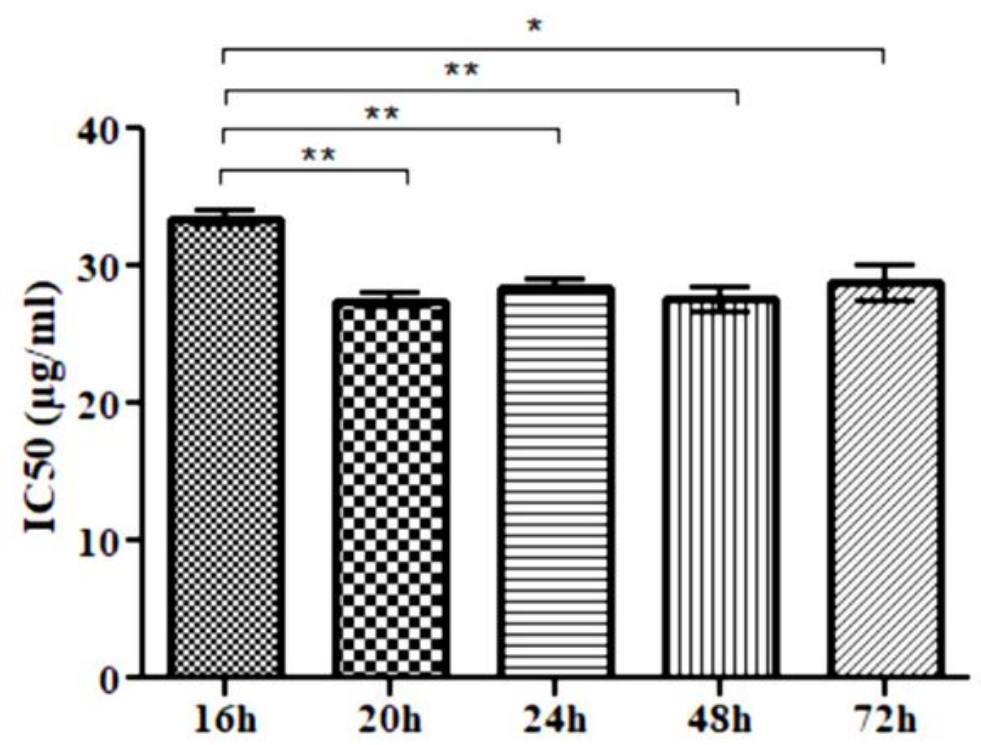

Figure 1

Effect of SPNs on HT-29 cells proliferation. A) Cell viability of HT-29 cells after treatment of SPNs with different concentrations $(0-200 \mu \mathrm{g} / \mathrm{mL})$ for 16 to $72 \mathrm{~h}$. B) Statistical analysis of the half maximal inhibitory concentration (IC50) of SPNs $(\mu \mathrm{g} / \mathrm{ml})$ during 16 to $72 \mathrm{~h}$. The results are presented as mean \pm $\mathrm{SD} ;{ }^{*} \mathrm{P}<0.05,{ }^{\star} * \mathrm{P}<0.01$. 


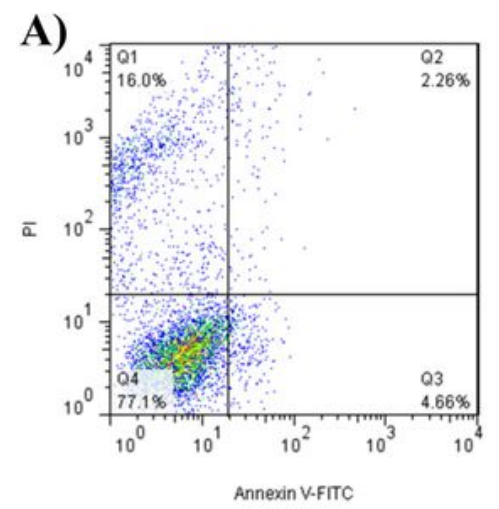

Control cells

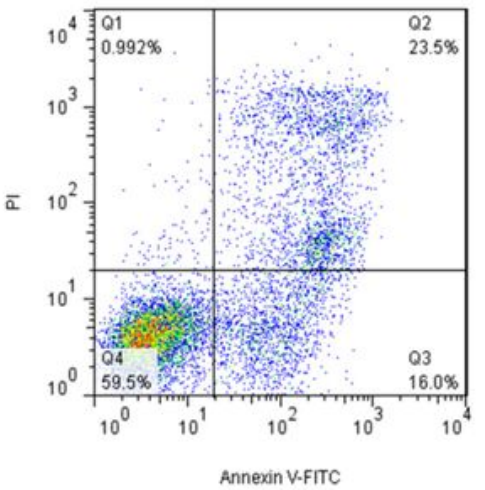

$40 \mu \mathrm{g} / \mathrm{ml}$

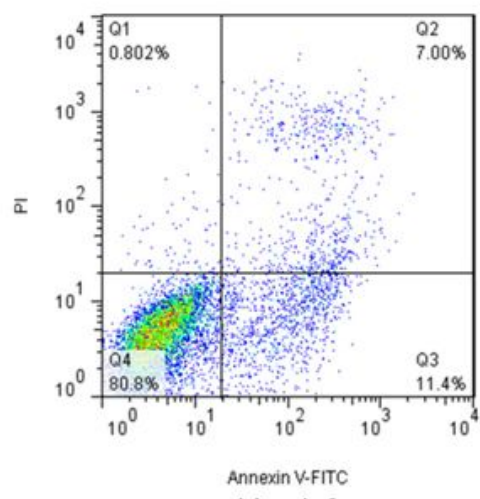

$14 \mu \mathrm{g} / \mathrm{ml}$

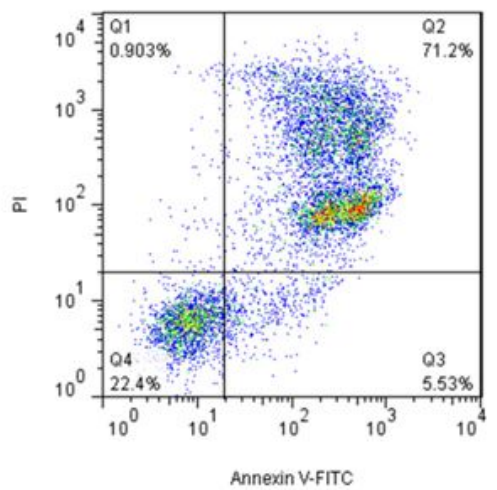

$50 \mu \mathrm{g} / \mathrm{ml}$

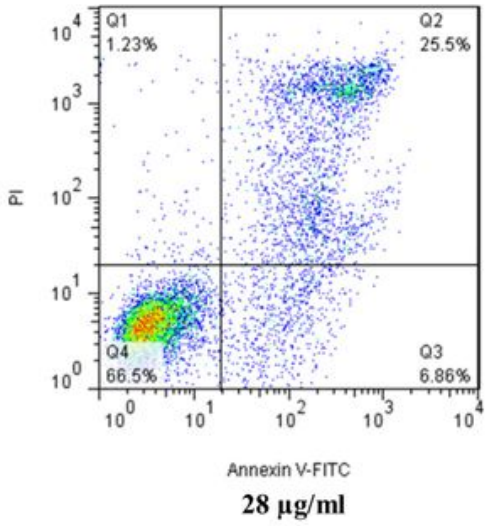

$28 \mu \mathrm{g} / \mathrm{ml}$

B)

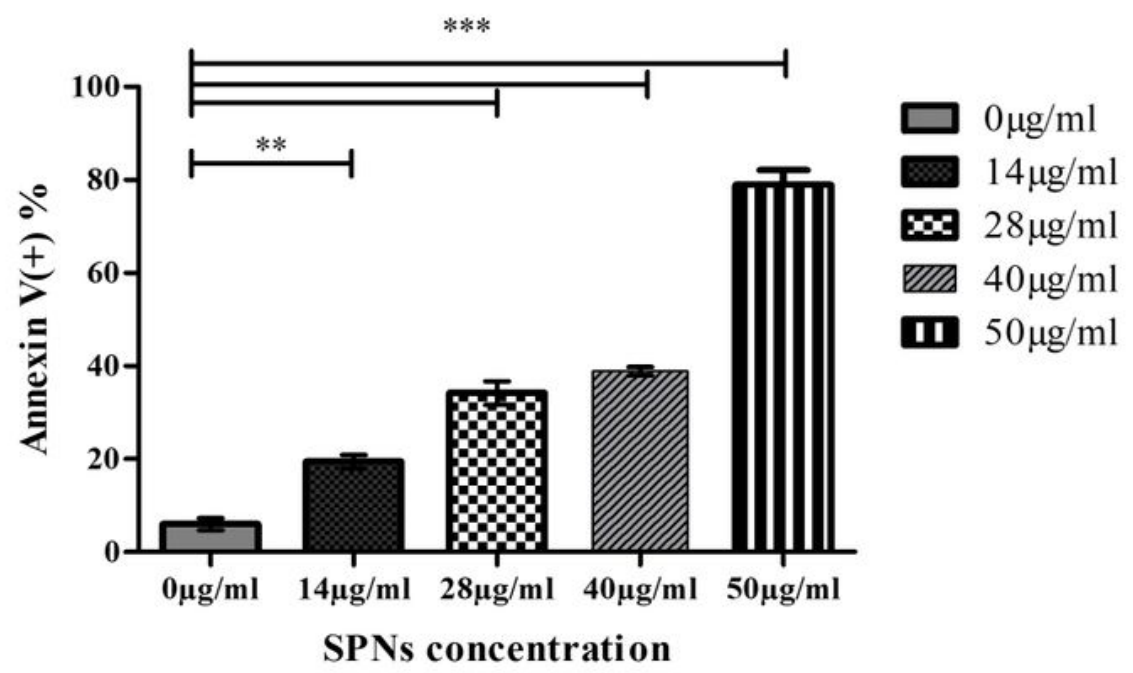

Figure 2

Flow cytometry analysis of AnnexinV/PI staining of HT-29 cells after induction of SPNs for $24 \mathrm{~h}$ with the concentrations of $0 \mu \mathrm{g} / \mathrm{ml}, 14 \mu \mathrm{g} / \mathrm{ml}$, and $28 \mu \mathrm{g} / \mathrm{ml}, 40 \mu \mathrm{g} / \mathrm{ml}$, and $50 \mu \mathrm{g} / \mathrm{ml}$ (A). B) Statistical analysis of Annexin V (+) cell percentage after treatment with SPNs for $24 \mathrm{~h}(0,14,28,40$, and $50 \mu \mathrm{g} / \mathrm{ml})$. Data was expressed as mean \pm standard deviation. ${ }^{*} \mathrm{P}<0.01 ; * \star \star \mathrm{P}<0.001$. 

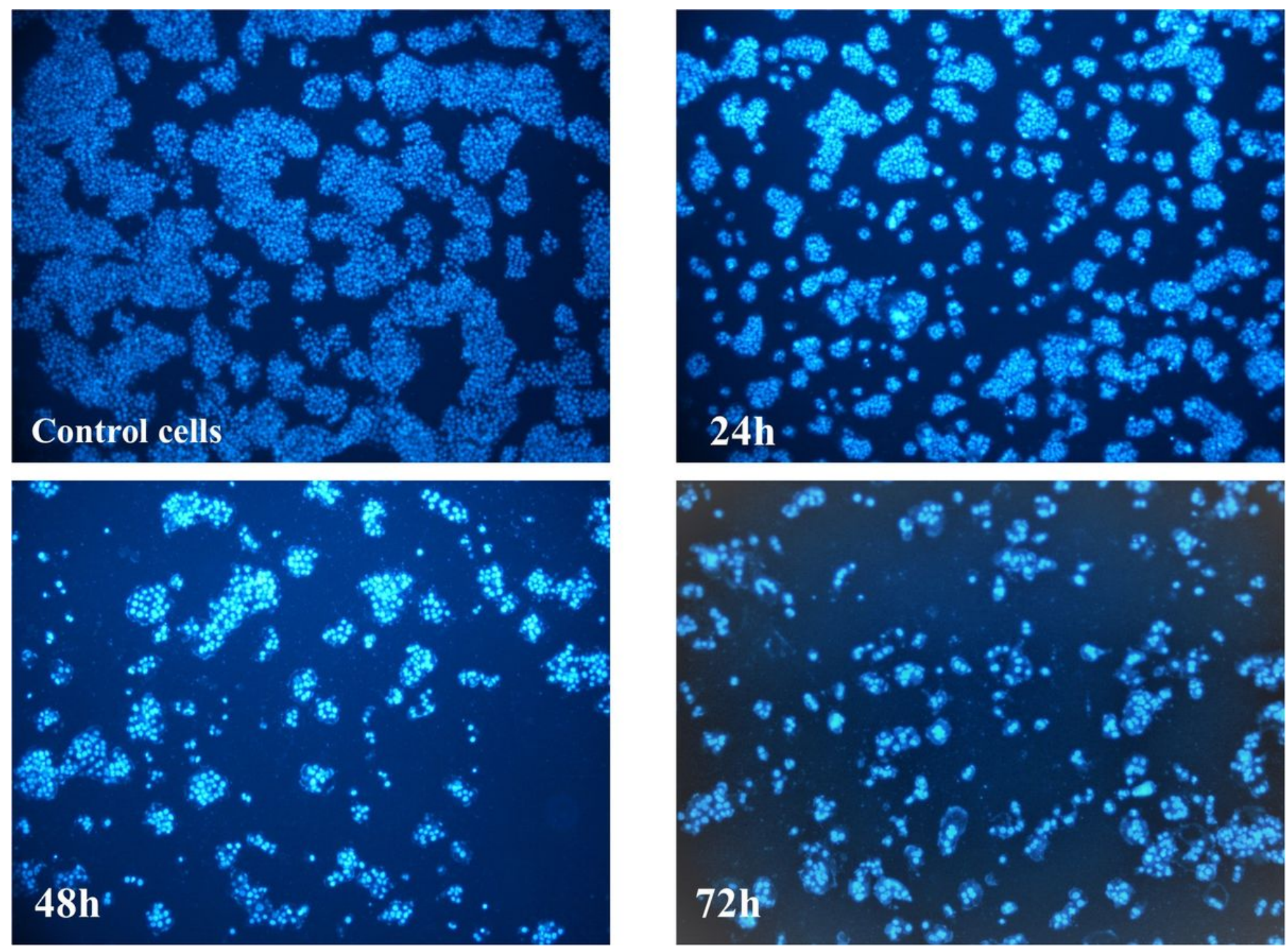

Figure 3

Apoptosis detection by DAPI staining. HT-29 cells were treated with SPNs at IC50 concentration $(28 \mu \mathrm{g} / \mathrm{ml})$ and incubation for $24 \mathrm{~h}, 48 \mathrm{~h}$, and $72 \mathrm{~h}$. The untreated cells were remained completely and shaped, were as apoptotic cells became visible in a time-dependent manner after treatment with SPNs (Magnification, 10X). 
A)
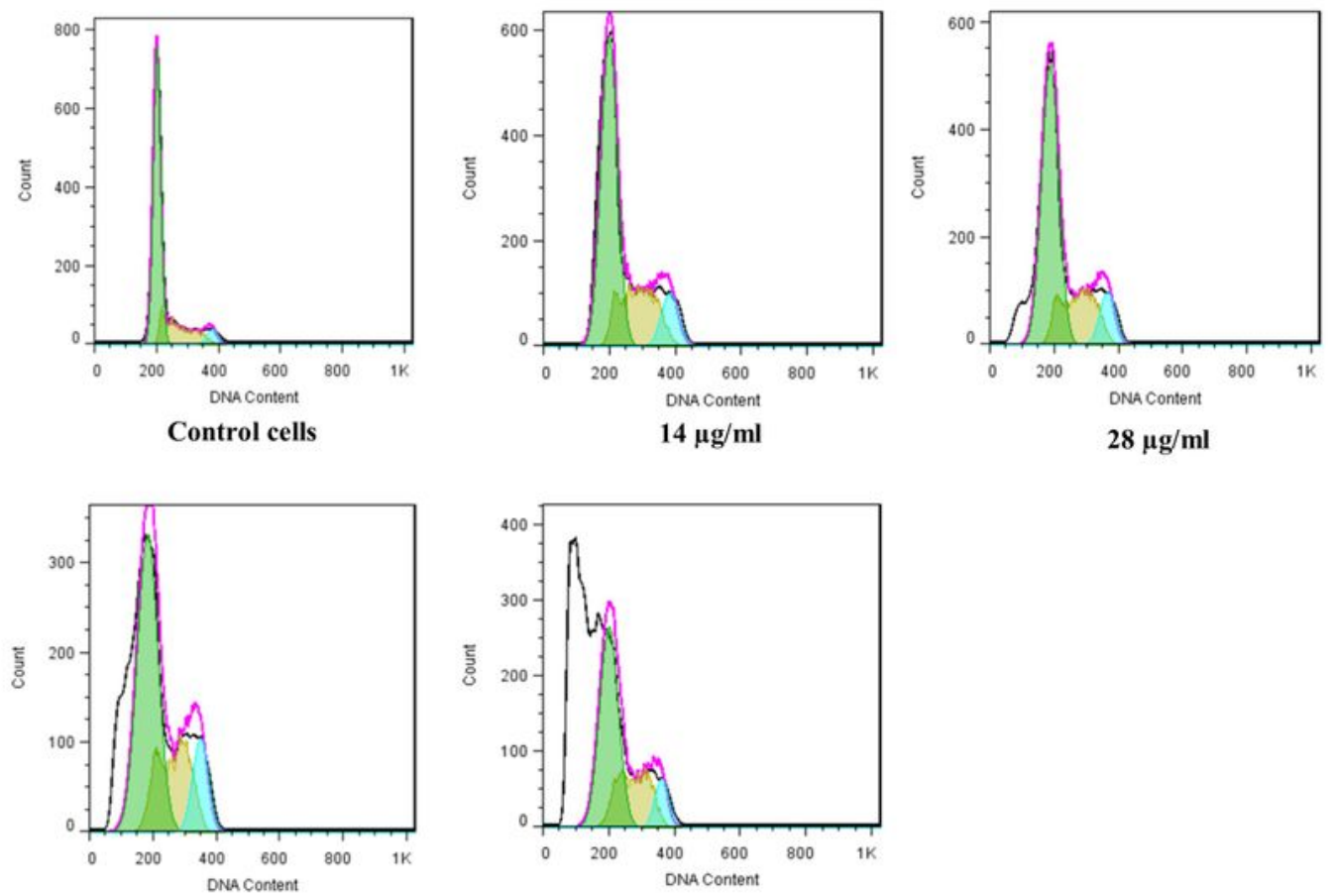

$40 \mu \mathrm{g} / \mathrm{ml}$

$50 \mu \mathrm{g} / \mathrm{ml}$

B)

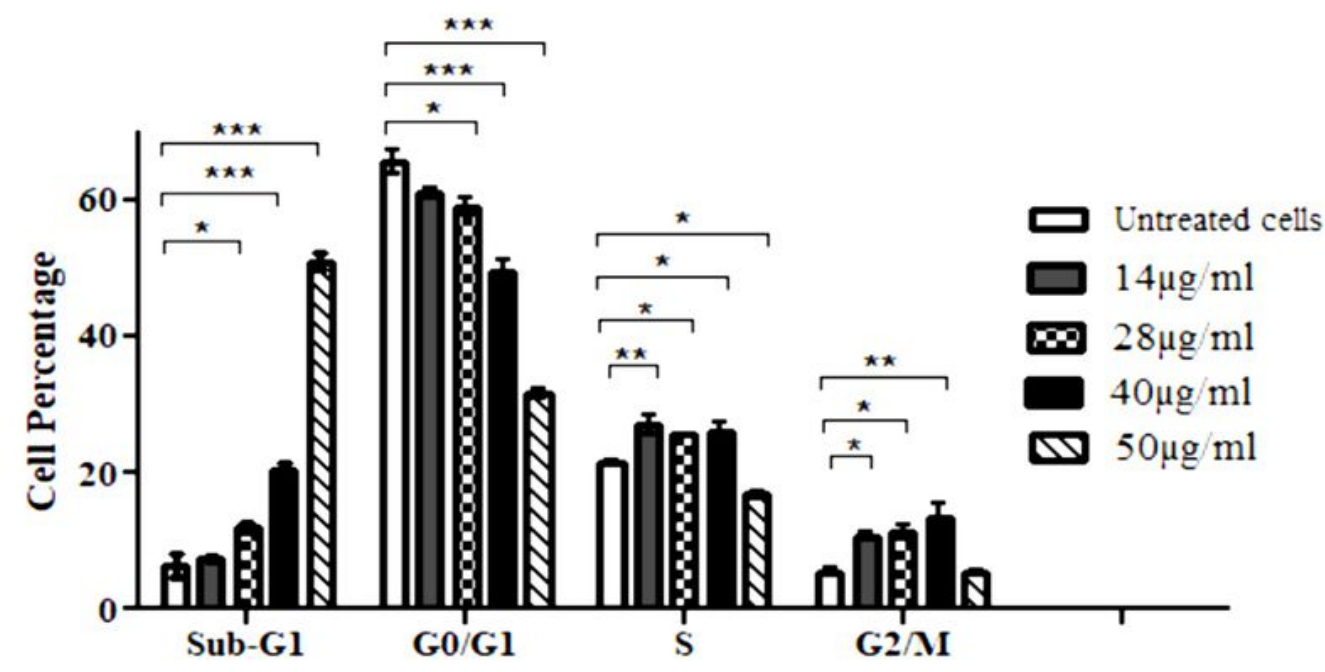

Figure 4

cell cycle analysis of HT-29 cells. A) Cell cycle distribution after $24 \mathrm{~h}$ of dose-dependent manner with SPNs $(0,14,28,40$, and $50 \mu \mathrm{g} / \mathrm{ml})$ using flow cytometry analysis. B) Statistical analysis of cell percentage in each phase after staining with Propidium lodide (PI) during 24h compared in treatment different doses. The results are presented as mean $\pm S D$. ${ }^{*} P<0.05,{ }^{\star \star} P<0.01,{ }^{* \star *} P<0.001$. 

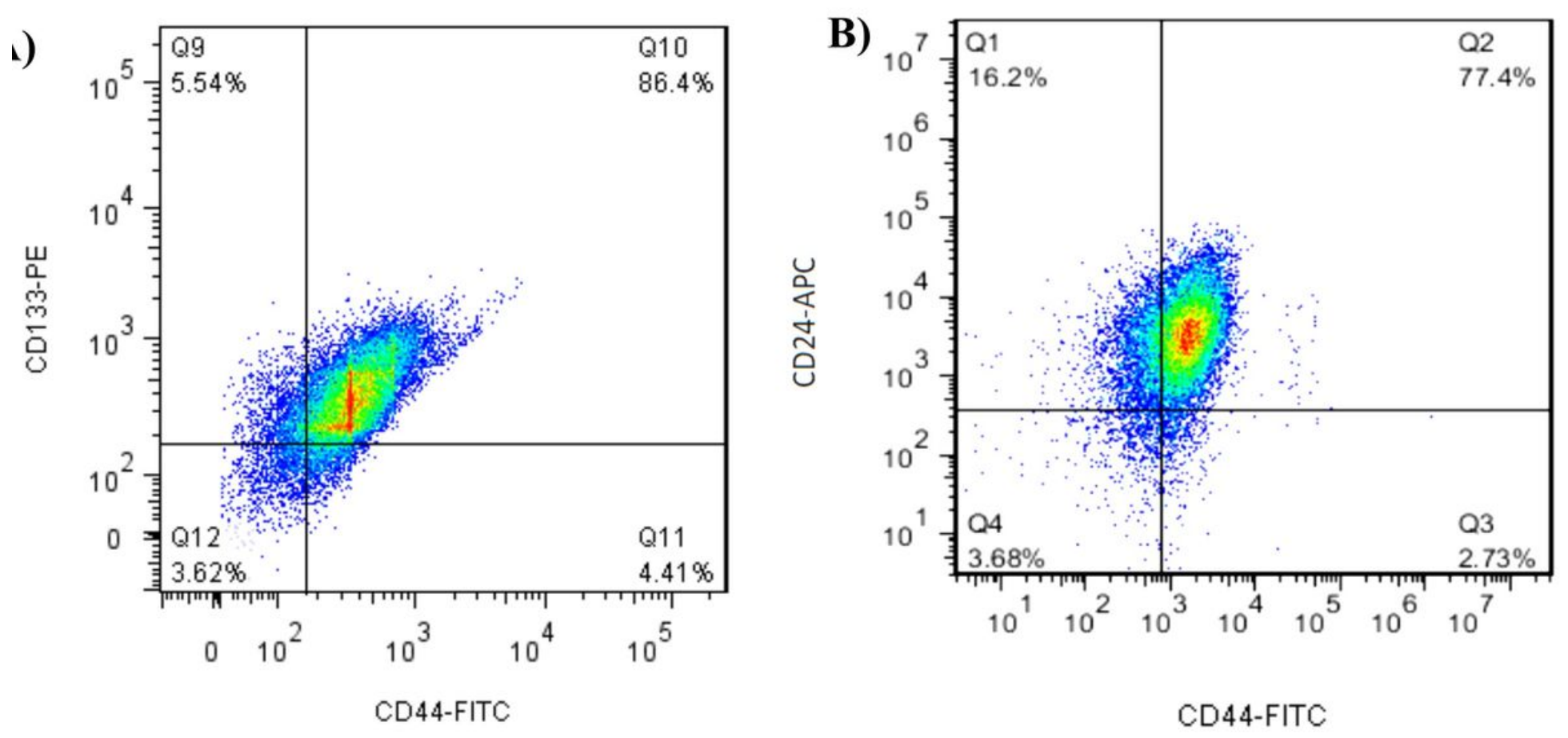

Figure 5

Evaluation of HT29 cancer cell line for expression level of stem cell surface markers. Flowcytometry result of expression level of CD44+/ CD133+ cells (A), and CD44+/ CD24+ cells (B) were $\nabla 86.4 \%$ and $\nabla$ $77.4 \%$ in untreated HT-29 CSCs, respectively. 

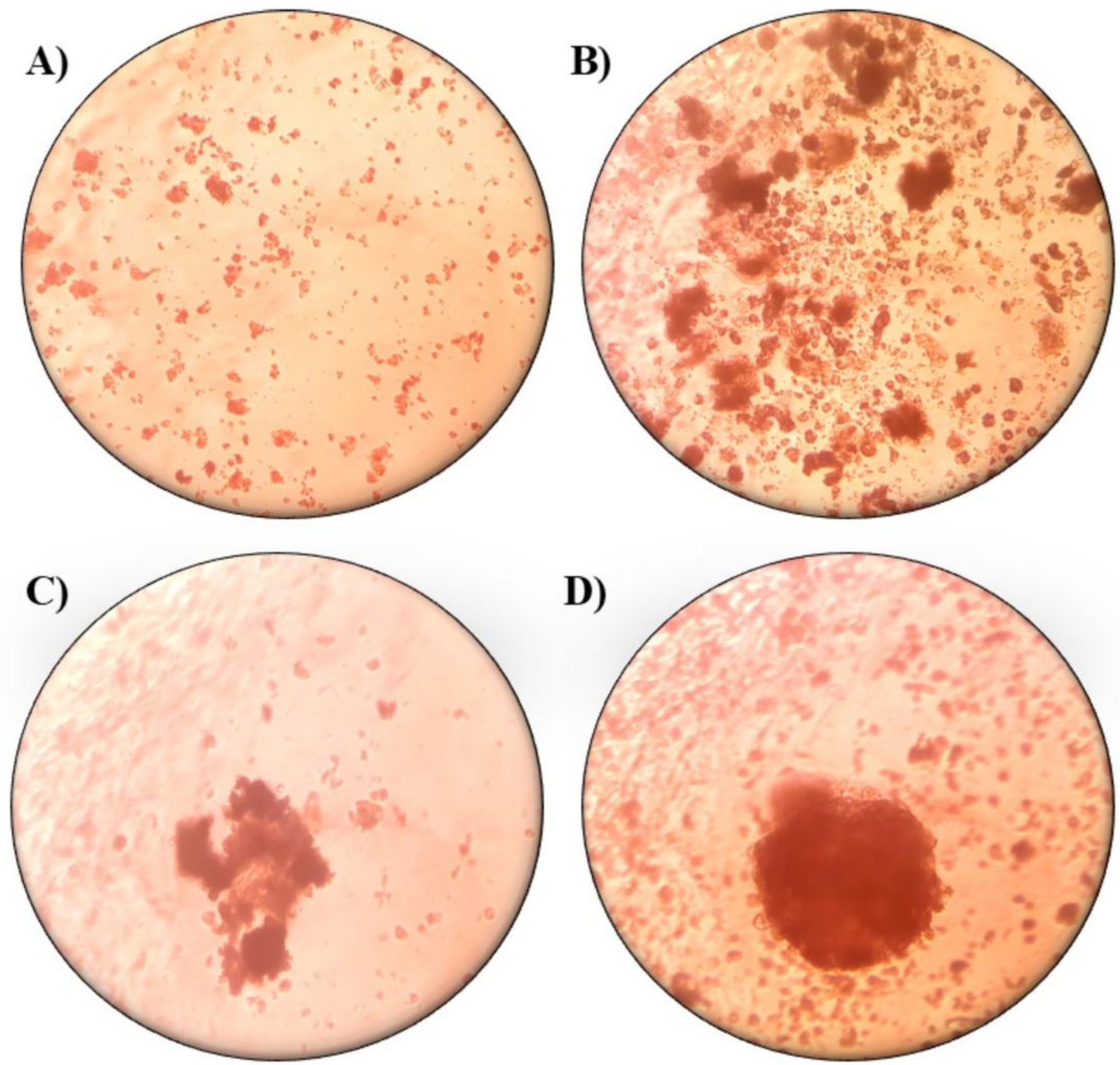

\section{Figure 6}

Hanging drop assay for HT-29 spheroid forming capacity after incubation in $37^{\circ} \mathrm{C}$ for 3days (A), 5 days (B), 7days (C), and 10days (D). MCTSs was emerged after 3days and completely condensed after 10 days of incubation. 

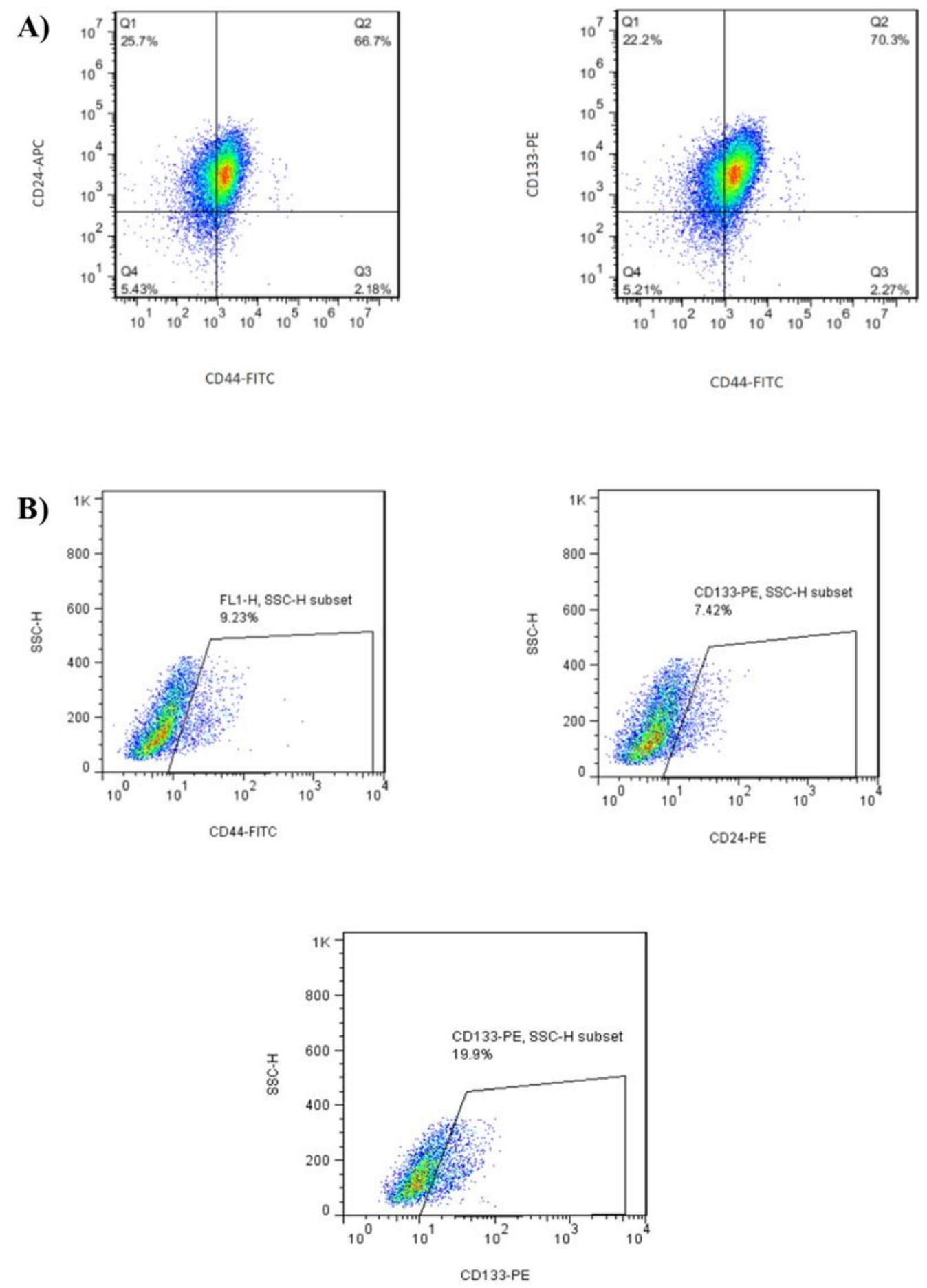

\section{Figure 7}

Assessment of HT-29 CSCs drug response in two different model of cancer cells. Flowcytometry analysis of multicellular spheroid forms(A), and single cell suspension(B) after treatment with SPN at IC50 dose for $24 \mathrm{~h}$. The results demonstrated that treatment of single cell suspension was more effective than multicellular spheroid form. 
A)

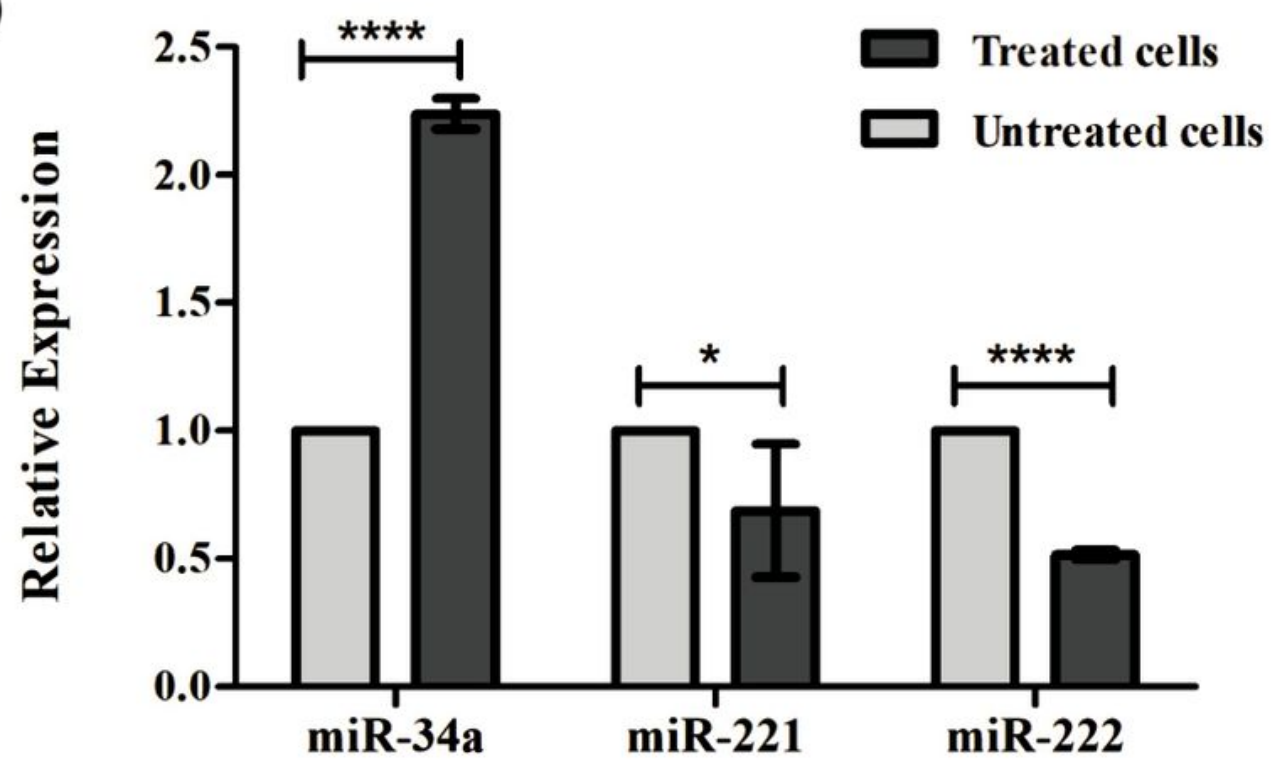

B)

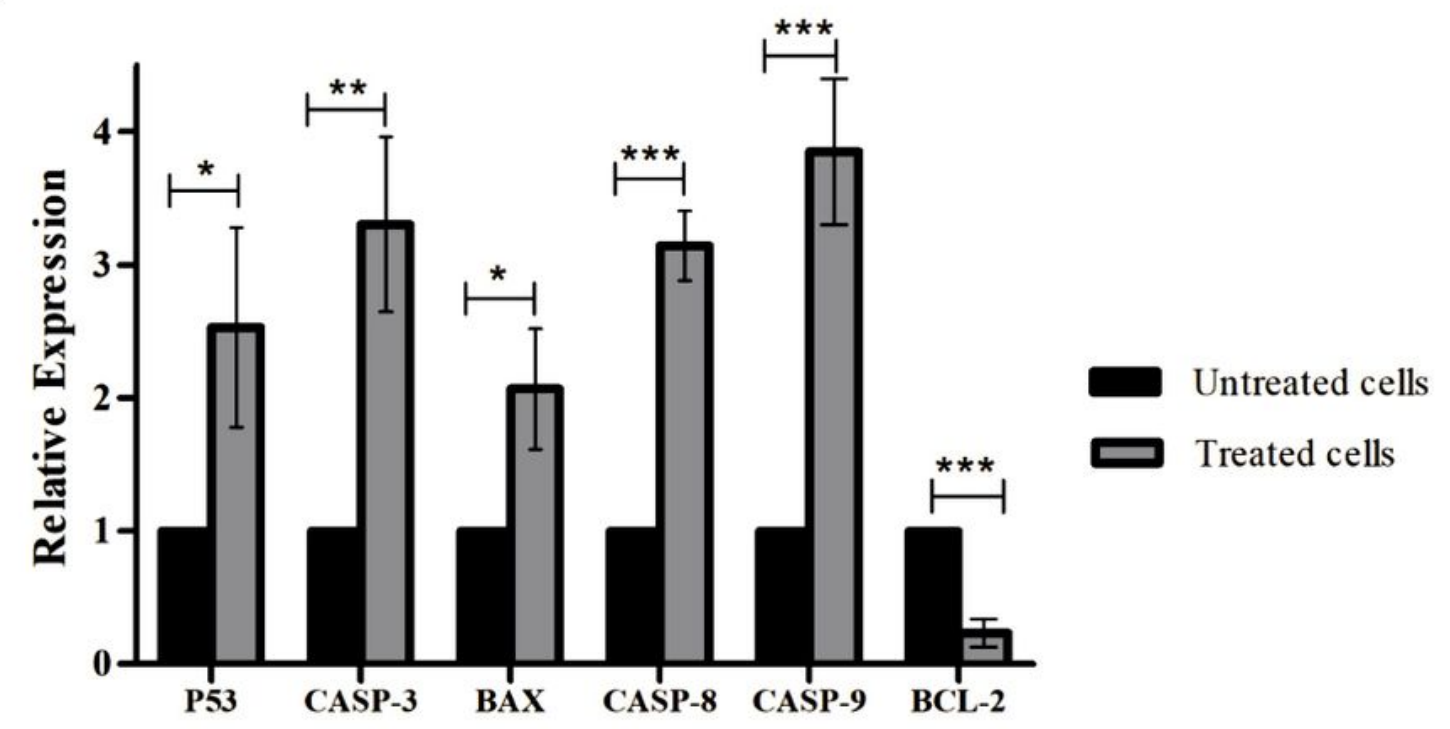

Figure 8

(A) The expression level of miR-34a, miR-221 and miR-222 after treatment with SPNs $(28 \mu \mathrm{g} / \mathrm{ml})$. Relative expression was normalized to U47 snRNA as an endogenous control. All of the expression folds had significantly difference with untreated cells with $P<0.001$ ( ${ }^{\star} P<0.05$, ${ }^{\star \star *} P<0.001$ ). (B) Quantitative expression of P53, CASP3, BAX, CASP8, CASP9, and BCL2 in treated cells with SPNs $(28 \mu \mathrm{g} / \mathrm{ml})$ compared 
to control group. Relative expression of target genes was normalized to HPRT1. Results was expressed as mean $\pm S D ; * P<0.05, * * P<0.01, * * * P<0.001$. 